\title{
Agriculture and Law in Japanese Society
}

\section{Rolnictwo i prawo w społeczeństwie japońskim}

\author{
Shinji Shimogaki, JD \\ Numata City OFFICE \\ 888, Shimonocho, Numata CITy, GunMa PrefECTURE, 378-8501, JAPAN \\ shinjing_720@yahoo.co.jp
}

\begin{abstract}
This study analyzes the changes in farmland system in Japan. The main policy of post-World War II Japan was regulation of the transfer lease or ownership of farmland, and the conversion of agricultural land into nonagricultural land considering the importance of farmlands. Paradoxically, this policy created some problems, such subdivision of farmland and ownerless lands. To address these problems, the Farmland Intermediary Management Institution was established in 2014 to accelerate farmland concentration and intensify the power of core farmers. In 2016, The Agricultural Land Act was reformed to make it easier for stock companies to own farmland. And, ICT has enabled us to visualize and verbalize tacit knowledge. This study explores the outcomes of these reforms and other unanswered issues.
\end{abstract}

\begin{abstract}
Abstrakt
Artykuł analizuje zmiany w japońskim systemie pól uprawnych. Głównym podejściem powojennej Japonii były przepisy dotyczące przeniesienia dzierżawy lub własności pól uprawnych oraz odrolnienie ziemi. Paradoksalnie, podejście to doprowadziło do powstania takich problemów jak podział ziemi uprawnej i ziem niczyich. W celu przyspieszenia koncentracji gruntów rolnych i wzmocnienia siły rolników wieloobszarowych powołano w 2014 roku Instytut Zarządzania Użytkami Rolnymi. W roku 2016 zreformowano ustawę o gruntach rolnych aby ułatwić spółkom akcyjnym posiadanie gruntów rolnych, podczas gdy technologie ICT pozwoliły na zwizualizowanie i wyrażenie wiedzy ukrytej. Artykuł bada m.in. wyniki tych reform.
\end{abstract}




\section{Introduction}

Farmland is the basic production factor for food supply to the nation and is also an important infrastructure for producers. It is especially precious in Japan's natural environment of: $66 \%$ of the land is mountainous with forests, and cultivated land is only $12 \%$. $\left(44,440\right.$ square kilometers $\left.{ }^{1}\right)$.

However, there has been an increase in deserted cultivated lands and farmlands whose owners are unknown. Japan's food self-sufficiency rate-on a calorie basis-remains low, at around 38\% in 2016.

Considering prospective development, this study attempts to find solutions to these issues, besides exploring other unanswered issues.

\section{Profile of Japanese farmland and the main policy}

The profile of farmers and farmlands before World War II is described as follows.

The farmers were generally classified into three categories; landowner, peasant proprietor, and tenant farmer. The landowner lends his land either totally or partly and lives off the rent, a peasant proprietor cultivates his own land and earns his living from the harvests, and the tenant farmer rents land from the landowner and farms them himself. According to a statistical report from the end of 1912, 32\% of all farmers were peasant proprietors, $28 \%$ were tenant farmers, and $40 \%$ of them were peasant proprietors as well as tenant farmers (Agricultural Bureau, Dept. of Agriculture and Commerce, 1914:3). There also was a small number of landlords who simply owned their land but did not cultivate it by themselves.

In 1946, the Japanese Government imposed a series of measures for farmland reform. The decision was taken under the initiative of GHQ (General Headquarters of occupying forces of the Allies). The purpose of this reform was to democratize Japanese society's feudal system.

Landlords who went over the limit had to sell their excess land to the government at a fixed price. The government then sold it at the same price, giving first preference to any tenant who had been farming the land. The GHQ held the power to deprive the interests of the privileged class, which dramatically enforced the reform of Japanese society.

Through this reform, the farmland diffuses into a huge number of farmers. The importance of the self-owned land by cultivators themselves had been emphasized ${ }^{2}$.

${ }^{1}$ http://www.maff.go.jp/j/tokei/kekka_gaiyou/sakumotu/menseki/h29/kouti/index.html (accessed June 1, 2018)

2 Agricultural Land Act Article 1: Given that agricultural land constitutes a basis for agricultural production in the country and provides resources that are both finite for present and future citizens and precious for local areas, the purpose of this Act is-in light of the important role that has been played by the ownership of agricultural land by 
Permission from the agricultural commission was required to transfer
the ownership of cropland or meadow/pasture land, or to establish/transfer a superficies, emphyteusis, pledge, right by loan for use, right of lease, or any other right to use/derive profit (Agricultural Land Act, Article 3(1) main clause3; Takagi and Naito, 2017: 59).

Ownership of agricultural land by cultivators was considered to be most appropriate. This also meant that the land could not be owned by stock companies, because only natural farmers could directly cultivate it. The stock companies only had an ideological status of legal entities, which implied that they could not cultivate it directly.

By regulating the conversion of land into non-agricultural land, the status of cultivators was stabilized, and the domestic agricultural production was boosted (Agricultural Land Act, Article 4(1) 4 and 5(1) 5; Takagi and Naito, 2017: 119-180). In other words, the principle of using farmland properly as an agricultural resource was developed.

Consequently, a large number of small-scale farmers had small farmlands in Japan. This was the situation after World War II.

\section{Change in situation}

However, the situation has changed in the last few decades.

During the economic growth period (the 1970s), The farmlands were left by farmers, who abandoned the countryside and migrated to the cities. Industry and commerce gained more recognition than agriculture. Imported food became cheaper than domestically produced food. In addition, the restrictions in transferring ownership and establishing right of lease accelerated the increase of abandoned farmlands. Today,

cultivators themselves-to stabilize the status of cultivators and boost domestic agricultural production by regulating the conversion of such land into non-agricultural land, promote the acquisition of rights to agricultural land by cultivators who make efficient use of such land in consideration of harmony with local areas, adjust relations over the use of such land, and take measures to secure the agricultural use of such land.

3 Article 3 (1): When a party transfers the ownership of cropland or meadow/pasture land, establishes a superficies, emphyteusis, pledge, a right by loan for use, a right of lease or any other right to use and derive profit from cropland or meadow/pasture land, or transfer such a right, that party must obtain permission from the agricultural commission pursuant to the provisions of Cabinet Order.

4 Article 4 (1): A person who converts cropland to non-cropland must obtain permission from the prefectural governor (or when that land is located in the area of the municipality that has been designated by the Minister of Agriculture, Forestry, and Fisheries in consideration of the status of implementation of the measures designed to ensure the agriculturally efficient and integrated use of cropland or meadow/pasture land (hereinafter referred to as "designated municipality"), the mayor of that designated municipality; hereinafter referred to as "head of the prefecture or the like")

5 Article 5 (1): When a party, for the purpose of converting cropland to noncropland or meadow/pasture land to non-meadow/pasture land (expect cropland; the same applies in the following paragraph and paragraph (4)) establishes or transfers a right to such land that is set forth in the main clause of Article 3, paragraph (1), that party must obtain permission from the head of the prefecture or the like.). 
abandoned farmlands cover up to $10 \%$ of our country $(4,500$ square kilometers).

Aged farmers and abandoned farmlands are serious problems, especially in rural areas. The number of farmers and population of rural communities are also decreasing.

If the number of farmers declines substantially, valuable resources and techniques related to agricultural management would not be passed on to the next generation. There is also a concern that the decline in population of rural communities would impede the maintenance and management of local resources such as farmlands and irrigation systems. This would also interfere with the functioning of life services among others.

Japanese agriculture actually faces a serious situation.

\section{Standing up for reform}

To address the problems discussed above, the government resolved to consolidate farmland for the large-scale farmers to increase efficiency.

For example, the Farmland Intermediary Management Institution (Farmland Bank) was established in 2014. The scheme is as follows: Farmland owner leases or entrusts land to the Farmland Bank. Next, the Farmland Bank leases farmland to large-scale farmers. In this case, permission from the agricultural commission is not required (Agricultural Land Act, Article 3(1) (iii) ${ }^{6}$.

Farmland subleased by the Farmland Bank was 43,00o ha at the start of FY 2016; this reached 142,000 ha by the end of the year. Given the target of raising the business share of farmers to $80 \%$ by FY 2023, the Farmland Bank is now required to accelerate farmland consolidation in cooperation with agricultural committee members to optimize the farmland usage and infrastructure (Ministry of Agriculture, Forestry, and Fisheries 2018:21).

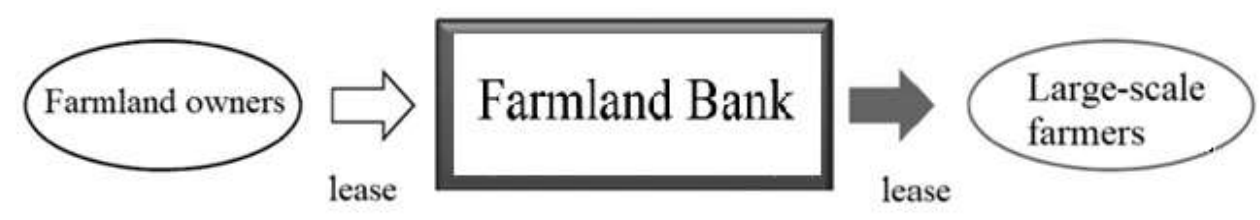

+The permission from the agricultural commission is not required.

(Agricultural Land Act article 3(1) (iii)).

Figure 1. The system of Farmland Bank.

\footnotetext{
${ }^{6}$ Article 3 (1) (iii): a case where the farmland intermediary management right (as provided for in Article 2, paragraph (5) of the Act on Promotion of the Farmland Intermediary Management Program; the same applies hereinafter) is established pursuant to the provisions of Articles 37 to 40 inclusive.
} 
In addition, in order to develop large-scale farmlands, the stock companies were allowed to lease farmland in 2009 , and they were finally granted a right to own the farmland in 2016 ("judicial person qualified to own farmland," Agricultural Land Act, Article 2 (3))7. This amendment aimed at empowering large-scale management using capital strength. Consequently, the number of companies and corporations has grown up to 3,030 in 2017 , from only 427 in $2009^{8}$.

The farmers' share of the total farmland in FY 2016 rose up to $54 \%$, an increase of 1.7 points from the previous year (Ministry of Agriculture, Forestry, and Fisheries 2018:21).

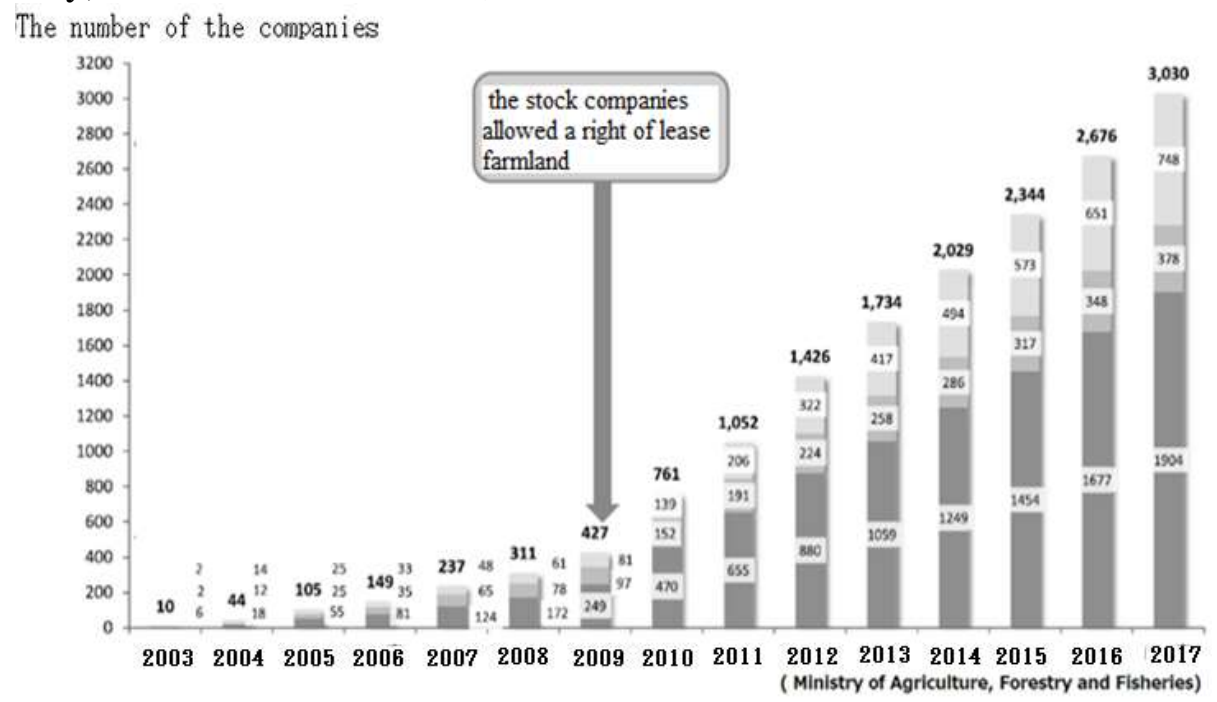

Figure 2. Number of companies to entry in agriculture 9

In the midst of a labor crisis, the ministry is making efforts to realize a new agriculture system, which will help the workforce by utilizing robot technology and ICT. They aim to expand the number of young people engaged in agriculture, forestry, and fisheries, and also improve manpower

\footnotetext{
7 Article 2 (3): The term "judicial person qualified to own farmland" as used in this Act means an agricultural producers' cooperative judicial person, stock company (that is not a public company provided for in Article 2, item (v) of the Companies Act (Act No. 86 of 2005) (Article 2, item (v) of the same Act : "Public Company" means any Stock Company the articles of incorporation of which do not require, as a feature of all or part of its shares, the approval of the Stock Company for the acquisition of such shares by transfer); the same applies hereinafter) or membership company (as provided for in Article 575, paragraph (1) of the same Act (Article 575 paragraph (1): In order to incorporate an General Partnership Company, Limited Partnership Company or Limited Liability Company (hereinafter collectively referred to as "Membership Company"), persons who intend to be its partners must prepare articles of incorporation which must be signed by or record the names of and be affixed with the seals, of all partners.); the same applies hereinafter) that satisfies all of the following requirements.

8 www.maff.go.jp/j/keiei/koukai/sannyu/attach/pdf/kigyou_sannyu-11.pdf (accessed September 4, 2018)

${ }^{9}$ www.maff.go.jp/j/keiei/koukai/sannyu/attach/pdf/kigyou_sannyu-11.pdf
} 
and cost efficiency (Ministry of Agriculture, Forestry, and Fisheries 2105.12).

In order to make use of unclaimed farmland-accounting for $20 \%$ of the total farmland-a bill has been submitted to the National Diet (Japan's bicameral legislature), allowing farmland successors to rent it for up to 20 years to Farmland Bank with simple procedures (Ministry of Agriculture, Forestry, and Fisheries 2018:21).

Gradually, the policy has begun to show its effect.

\section{Challenges}

The emergence of the Farmland Bank and the stock companies in agriculture has helped achieve economic growth in Japan.

However, in my opinion, the most important challenge is to secure human resources. Farmlands are diverse in conditions and therefore vary considerably from one region to another.

In a situation where farmers are aging, transfer of knowledge to the next generation is particularly important.

Various intellectual properties have been accumulated through extended activities in the food industry-agriculture, forestry, fisheries, and other related industries (hereinafter referred to as the "food industry, etc."). The food industry, etc. is now positioned as a knowledgebased/information industry (Ministry of Agriculture, Forestry, and Fisheries 2015:1).

And most of the knowledge, such as traditional knowledge or empirical rule is succeeded by heredity; or a "tacit knowledge", so to speak. Most of them are undescribed.

Finding a way to pass on this knowledge to the newer generations, such as the non-agricultural stock companies, is the key to the growth of Japanese agriculture.

\section{Utilization of ICT}

It is difficult to verbalize tacit knowledge. However, these days, ICT (information and communication technology) has enabled us to visualize such knowledge.

Keio University focuses on the tacit knowledge behind the productivity of skilled Japanese farmers and tries to translate this into formal knowledge that can be passed on to future generations.

Keio University has worked with IT (Information Technology) companies to build a platform that utilizes IT to improve agricultural production efficiency.

One of the approaches is as follows: Sensors and AI analyze the movement of the skilled farmer's view and gaze point and researchers analyze the integrated data.

The Ministry of Agriculture, Forestry, and Fisheries will promote the appropriate utilization of business models and intellectual property to recover from the delay caused by biotechnology, ICT, artificial intelligence, and other such cutting-edge technologies used by the Japanese 
food industry (Ministry of Agriculture, Forestry, and Fisheries 2015:5). They will systematize the methods of skilled farmers using ICT and send the results back to the farmers. The ministry will also promote the utilization of these results for a smoother transition of skills to the next generation, which would contribute not only to agriculture but also to the entire food industry (Ministry of Agriculture, Forestry, and Fisheries 2015:13).

In addition, not only the farmers' skills but also various types of agriculture-related data can be aggregated as big data through ICT utilization. The ministry will utilize the findings to promote education (Ministry of Agriculture, Forestry, and Fisheries 2015:13).

\section{Problem of intellectual property}

It is important to consider the appropriate protection of data obtained through ICT, since there is a concern that the dissemination of ICT in the agricultural field will be hindered because of the absence of an appropriate consensus on concerned interests for handling the intellectual properties in agriculture.

It is necessary to develop ethical sense that respects intellectual property, not only among producers, companies, and researchers but also the whole nation, including consumers. In the agricultural field, information has been provided for free, as if it was some sort of public property. However, such information includes public information that should be shared by all and-at the same time-private/regional information that should be individually owned. In principle, it is important to foster a sense where economically-valuable information is not disclosed without charge and a person receiving such information pays a legitimate compensation (Ministry of Agriculture, Forestry, and Fisheries 2015:5).

Producers being ignorant about intellectual property protection, despite their benefits, is a big issue. In particular, it is necessary for farmers to be aware that the methods they developed can be deemed as intellectual property (Ministry of Agriculture, Forestry, and Fisheries 2015:19).

On the other hand, protection of individual rights at the same time could cause a breach in the interest of the communities. This is truly an intellectual property of individuals; however, it is in the interest of the communities as well.

If a community member uses such an intellectual property, a person who owns this intellectual property could appeal for mandatory injunction. However, it is unbalanced in that it gives a near-monopoly status to that particular person, since the "tacit knowledge" is derived from the natural conditions.

On this point, WIPO (World Intellectual Property Organization) indicates the importance of "traditional knowledge."

The current international system for intellectual property protection was designed during the age of industrialization in the West. Subsequently, it developed along with the perceived needs of technologically advanced society. However, in recent years, indigenous people, local communities, 
and governments-mainly in developing countries-demanded equivalent protection for traditional knowledge systems ${ }^{10}$.

Traditional knowledge (TK) is the "tacit knowledge" that includes know-how, skills, and developed practices, sustained and passed on from generation to generation within a community, often forming a part of its cultural or spiritual identity ${ }^{11}$.

Innovations based on TK may benefit from patents, trademarks, and other protections while geographical indication may be protected under privacy laws. However, traditional knowledge-often old and passed through "word of mouth"-is not protected by conventional intellectual property systems ${ }^{12}$.

Tagami (2018: 77) has expressed concern about the antinomy of the intellectual property rights of the individual and the interests of the community. I share this concern. Innovations derived from tacit knowledge may benefit from patent and trademark protections, just as geographical indications are protected, but it is poor policy to grant nearmonopoly to persons on the basis of ancestral tacit knowledge.

\section{Closing remarks: the way ahead}

Farmlands and the "tacit knowledge" are the intellectual property of an individual. However, the interest of the communities should also be considered. Therefore, it is important and necessary to develop a harmonious system.

This study analyzes the changes in Japan's farmland system. The main policy of post-World War II Japan was to regulate the transfer lease or ownership of farmland, and ban the conversion of agricultural land into non-agricultural land for farmland protection. However, paradoxically, this policy brought about some issues, such as farmland subdivision or ownerless lands.

To address these problems, the Farmland Intermediary Management Institution was established in 2014 to accelerate farmland concentration and intensify the power of core farmers. In 2016, the Agricultural Land Act was reformed to make it easier for stock companies to own farmland.

However, in my opinion, the most important challenge is to secure human resources. Farmlands are diverse in conditions and therefore vary considerably from one region to another.

ICT has enabled us to visualize a verbalize tacit knowledge. It is necessary to develop ethical sense that respects intellectual property, not only among producers, companies, and researchers but also the whole

10 WIPO (World Intellectual Property Organization) “Traditional Knowledge and Intellectual Property - $\quad$ Background Brief", http://www.wipo.int/pressroom/en/briefs/tk_ip.html (accessed September 10, 2018)

11 WIPO (World Intellectual Property Organization), http://www.wipo.int/tk/en/tk/ (accessed September 10, 2018)

12 WIPO (World Intellectual Property Organization), http://www.wipo.int/tk/en/tk/ (accessed September 10, 2018) 
nation, including consumers. Moreover, it is important and necessary to develop a harmonious system about intellectual property protection.

It is important to consider the appropriate protection of data obtained through the introduction of ICT, since there is a concern that the dissemination of ICT in the agricultural field will be hindered because of the absence of an appropriate consensus on handling the intellectual properties related to agriculture.

This study also explores the outcomes of these reforms and other unanswered issues.

Future debates on, and developments in this field in Japan are certainly worthy of attention. 


\section{Bibliography}

Agricultural Bureau, Dept. of Agriculture and Commerce. 1914. Outlines of agriculture in Japan.

Ministry of Agriculture, Forestry and Fisheries. 2018. Summary of the Annual Report on Food, Agriculture and Rural Areas in Japan. http://www.maff.go.jp/e/data/publish/index.html\#Annual

Ministry of Agriculture, Forestry and Fisheries. 2015. Ministry of Agriculture, Forestry and Fisheries' Intellectual Property Strategy 2020.

Takagi, M., Naito, Y. 2017. Kaiteiban Chikujokaisetsu Nochihou. Taisei Shuppansha.

Tagami, M. 2015. Protection of Traditional knowledge. Jurist, Vol. 1521.

Watanabe, T. 2015. On the Aim of The Public Intermediate Organization for Farmland Consolidation. Research on Agricultural Law, Vol. 50: pp. 129140.

WIPO (World Intellectual Property Organization). Traditional Knowledge and Intellectual Property - $\quad$ Background Brief, http://www.wipo.int/pressroom/en/briefs/tk_ip.html (accessed September 10, 2018)

WIPO (World Intellectual Property Organization), http://www.wipo.int/tk/en/tk/ (accessed September 10, 2018)

WIPO (World Intellectual Property Organization), http://www.wipo.int/tk/en/tk/ (accessed September 10, 2018) 